\title{
PERCEPATAN PEMBUATAN GARAM DENGAN METODE SPRINKLE BERTINGKAT
}

\author{
ACCELERATION OF SALT PRODUCTION \\ USING MULTI-LEVEL SPRINKLE METHOD
}

\author{
Aris Kabul Pranoto ${ }^{1 *}$, Anthon A. Djari ${ }^{1}$, Roni Sewiko ${ }^{1}$, Larasati P. Hapsari ${ }^{1}$, \\ Haryanto $^{2}$, Chairil Anwar ${ }^{3}$ \\ ${ }^{1}$ Politeknik Kelautan dan Perikanan Karawang, Jalan Lingkar Tanjungpura, Karangpawitan, Kecamatan \\ Karawang Barat, Kabupaten Karawang, Jawa Barat 41315 \\ ${ }^{2}$ Bappeda Sultra, Jalan Komp. Bumi Kencana, Asih, Mokoau, Kambu, Kota Kendari, Sulawesi Tenggara \\ ${ }^{3}$ Politeknik Kelautan dan Perikanan Bone, Jalan Sungai Musi, Pallette, Tanete Riattang Tim., Kabupaten \\ Bone, Sulawesi Selatan 92719
}

Teregistrasi I tanggal: 23 April 2020; Diterima setelah perbaikan tanggal: 28 Mei 2020; Disetujui terbit tanggal: 15 Juli 2020

\begin{abstract}
ABSTRAK
Pada umumnya pembuatan garam secara tradisional menggunakan teknologi evaporasi air laut memerlukan waktu 20 hari per panen garam, sedangkan dengan metode Maduresse Berisolator memerlukan waktu 12 hari per panen garam. Tujuan penelitian ini adalah untuk melakukan inovasi teknologi evaporasi air laut dengan uji coba aplikasi teknologi tepat guna dalam percepatan pembuatan garam dengan Metode Sprinkle Bertingkat. Penelitian ini dilakukan selama 3 bulan mulai bulan Agustus sampai dengan bulan Oktober 2019 sebanyak 30 kali ulangan dan menghasilkan data rata - rata $3{ }^{\circ} \mathrm{Be}$ menjadi $9,78^{\circ} \mathrm{Be}$ per hari. Hasil penelitian ini dengan Metode Sprinkle Bertingkat dalam waktu 6 hari menghasilkan kristal garam atau lebih cepat 6 hari per panen, jika dibandingkan dengan Metode Maduresse Berisolator. Percepatan pembuatan garam ini terjadi karena adanya inovasi teknologi dengan menambahkan alat berupa sprinkle yang berfungsi menyemprotkan air laut ke udara sehingga mempercepat terlepasnya $\mathrm{H} 2 \mathrm{O}$ dari air laut dan mempercepat terbentuknya kristal garam. Dengan demikian dapat disimpulkan bahwa Metode Sprinkle Bertingkat dapat diterapkan untuk mempercepat terbentuknya kristal garam, sehingga metode ini direkomendasikan sebagai inovasi teknologi dalam meningkatkan produksi garam.
\end{abstract}

Kata kunci: Teknologi Evaporasi, Maduresse Berisolator, Sprinkle Bertingkat

\begin{abstract}
In general, traditional salt making using seawater evaporation technology requires 20 days per salt harvest, while the Maduresse Isolator method takes 12 days per salt harvest. The purpose of this study is to innovate seawater evaporation technology by testing the application of appropriate technology in accelerating the manufacture of salt with the Spraced Sprinkle Method. This research was conducted for three months, from August to October 2019; it takes 30 replications and produced an average of $3^{\circ}$ Be to $9.78^{\circ}$ Be per day. The results of this study with the Spraced Sprinkle Method within six days produce salt crystals or faster six days per harvest when compared with the Maduresse Isolator Method. The acceleration of making salt is
\end{abstract}

\footnotetext{
Korespondensi penulis:

*Email: arispranoto@gmail.com

DOI: http://dx.doi.org/10.15578/plgc.v1i3.8882
} 
due to technological innovation by adding a sprinkle tool that functions to spray seawater into the air so that it accelerates the release of $\mathrm{H} 2 \mathrm{O}$ from seawater and accelerates the formation of salt crystals. Thus it can be concluded that the Spacedle Sprinkle Method can be applied to stimulate the formation of salt crystals, so this method is recommended as a technological innovation in increasing salt production.

\section{Keywords: Evaporation Technology, Maduresse Isolator, Spraced Sprinkle}

\section{PENDAHULUAN}

Proses pembuatan garam bahan baku di Indonesia yang berasal dari air laut menggunakan sistem penguapan (evaporasi) air laut dengan menggunakan sinar matahari (solar energy) di atas tanah. Pada dasarnya pembuatan garam dengan bahan baku air laut berupa proses pemetakan (dengan menggunakan airnya) dan pemisahan garam (dengan kristalisasi). Pada saat terjadi kristalisasi komponen garam bahan baku tersebut diatur pada tempat yang berlainan secara berturut - turut, maka dapat dipisahkan komponen garam bahan baku yang relatif murni (Wahyuni, 2007 in Sartono et al., 2012).

Penentuan musim produksi garam diambil dari rata - rata hasil pengamatan intern data stasiun cuaca di lahan penggaraman maupun extern data dari Badan Meteorologi dan Geofisika. Iklim di Indonesia secara umum dibagi dalam 2 (dua) musim yaitu musim kemarau (kering) dan musim penghujan (basah), dimana batas keduanya kurang jelas sehingga permulaan dan akhir musim tersebut selalu berubah - ubah pada setiap tahunnya (Pranoto, 2012).

Faktor yang mempengaruhi produksi garam meliputi : (i) mutu air laut, terutama dari aspek kadar garamnya termasuk kontaminasi dengan air sungai sangat mempengaruhi waktu yang diperlukan untuk penguapan (evaporasi) air laut; (ii) cuaca/iklim mempengaruhi panjang musim kemarau yang berpengaruh langsung dalam proses produksi garam dengan bantuan sinar matahari; (iii) intensitas curah hujan dan pola hujan distribusinya dalam setahun rata - rata merupakan indikator yang 108 berkaitan dengan panjang kemarau yang kesemuanya mempengaruhi daya penguapan (evaporasi) air laut; (iv) kecepatan angin, kelembaban udara dan suhu udara sangat mempengaruhi kecepatan penguapan (evaporasi) air laut, dimana makin besar penguapan (evaporasi) makin besar jumlah kristal garam yang mengendap; (v) sifat porositas tanah mempengaruhi kecepatan perembesan (kebocoran) air laut bahan baku kedalam tanah yang ada di petakan peminihan maupun di petakan meja kristalisasi, bila kecepatan perembesan ini lebih besar daripada kecepatan penguapannya dan jika terjadi hujan selama pembuatan garam, maka tidak akan dihasilkan garam. Jenis tanah mempengaruhi pula warna dan ketidakmurnian (impurity) yang terbawa oleh garam yang dihasilkan; (vi) pengaturan aliran dan tebal dari petakan peminihan satu ke berikutnya dalam kaitannya dengan faktor arah kecepatan angin dan kelembaban udara merupakan gabungan penguapan air (koefisien pemindahan massa), pada saat proses kristalisasi garam konsentrasi air tua harus antara 25 - 29 derajat baume. Bila konsentrasi belum mencapai 25 derajat baume maka gips (Kalium Sulfat) akan banyak mengendap, bila konsentarsi air tua lebih dari 29 derajad baume Magnesium akan banyak mengendap (Pranoto, 2012).

Merujuk prinsip - prinsip dasar pembuatan garam tersebut, tujuan dilakukannya penelitian ini adalah untuk melakukan uji coba inovasi teknologi tepat guna dalam rangka percepatan pembuatan garam dengan Metode Sprinkle Bertingkat. 


\section{BAHAN DAN METODE}

Waktu dan Tempat

Penelitian ini dilakukan selama 3 bulan dari bulan Agustus sampai dengan bulan Oktober 2020 di lahan tambak garam PT. Garam Bahari Nusantara, Desa Ciparage Jaya, Kecamatan Tempuran,
Kabupaten Karawang, Provinsi Jawa Barat.

\section{Pengumpulan dan Analisis Data}

Alat dan bahan yang digunakan pada penelitian ini dapat dilihat pada Tabel 1 dan Tabel 2.

Tabel 1. Alat Penelitian

Table 1. Research Tools

\begin{tabular}{lll}
\hline No & \multicolumn{1}{c}{ Nama alat } & \multicolumn{1}{c}{ Fungsi } \\
\hline 1. & Pompa air & Mendorong air untuk melewati sprayer \\
2. & Baume meter & Menentukan massa jenis air \\
\hline
\end{tabular}

Tabel 2. Bahan Penelitian

Table 2. Research Needs

\begin{tabular}{lll}
\hline No & \multicolumn{1}{c}{ Nama alat } & \multicolumn{1}{c}{ Fungsi } \\
\hline 1. & Air laut & Bahan utama pembuatan garam \\
2. & Pipa Paralon & Untuk mengalirkan air dari masing-masing stasiun \\
3. & Geo Membrane & Sebagai alas tambak garam \\
\hline
\end{tabular}

Metode penelitian yang dilakukan dengan pendekatan metode percobaan dilakukan di tambak garam dengan Metode Sprinkle Bertingkat, di Desa Ciparage Jaya, Kecamatan Ciparage, Kabupaten Karawang. Teknologi Sprinkle bertingkat adalah proses percepatan penuaan air laut untuk menjadi garam kristal, yang dilakukan dengan cara:

a) Air laut baku dengan kadar baume sebesar 3 BE tersedia di saluran tambak garam;

b) Pemompaan air laut baku sebesar $3 \mathrm{BE}$ dialirkan ke SP1 (sprinkle tingkat pertama) pada pukul 08.00 WIB;

c) Setalah 2 jam, pada pukul $10.00 \mathrm{WIB}$, air laut baku dipompakan ke SP2;

d) Setelah 2 jam, pada pukul $12.00 \mathrm{WIB}$, air laut baku dipompakan ke SP3;

e) Setelah 2 jam pada oukul 14.00 WIB, air laut baku dipompakan ke SP4;

f) Proses dilakukan berlulang, sampai mendapatkan air laut baku untuk kristalisasi garam dengan kadar baume sebesar $25 \mathrm{BE}$;

g) Proses selanjutnya, setelah air laut baku untuk pembuatan garam dengan kadar baume sebesar $25{ }^{0} \mathrm{BE}$, dialirkan ke meja kristalisasi;

h) Proses evaporasi pada meja kristalisasi garam akan menjadi kristal garam.

Pengukuran parameter penelitian yaitu kadar Baume, diukur setiap 2 jam pada setiap sprinkle. Pengukuran dilakukan setiap 2-3 hari sejak 25 Agustus 2019 hingga 27 Oktober 2019.

\section{HASIL DAN BAHASAN HASIL}

Skema produksi garam dengan Metode Sprinkle Bertingkat dalam rangka percepatan pembuatan garam dapat dilihat pada Gambar 1. Saluran pemasukan air laut yang memiliki kualitas air dengan kondisi 3 derajat baume untuk dialirkan ke petakan Sprinkle tingkat pertama (SP1) dapat dilihat pada Gambar 2.

Agar penguapan air laut dapat berlangsung lebih cepat maka peralatan berupa pompa air dan pemipaan untuk mengalirkan melalui pipa dan sprinkle sebagaimana dapat dilihat pada Gambar 3. 


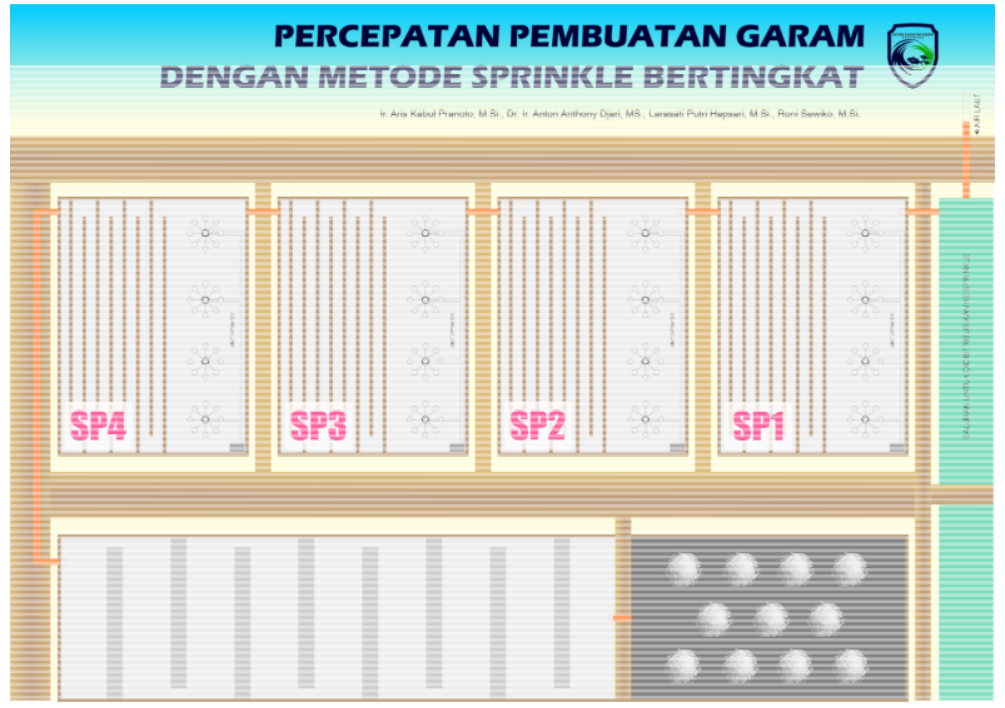

Gambar 1. Skema Produksi Garam dengan Metode Sprinkle Bertingkat Figure 1. Salt Production Scheme with Multi-Level Sprinkle Method

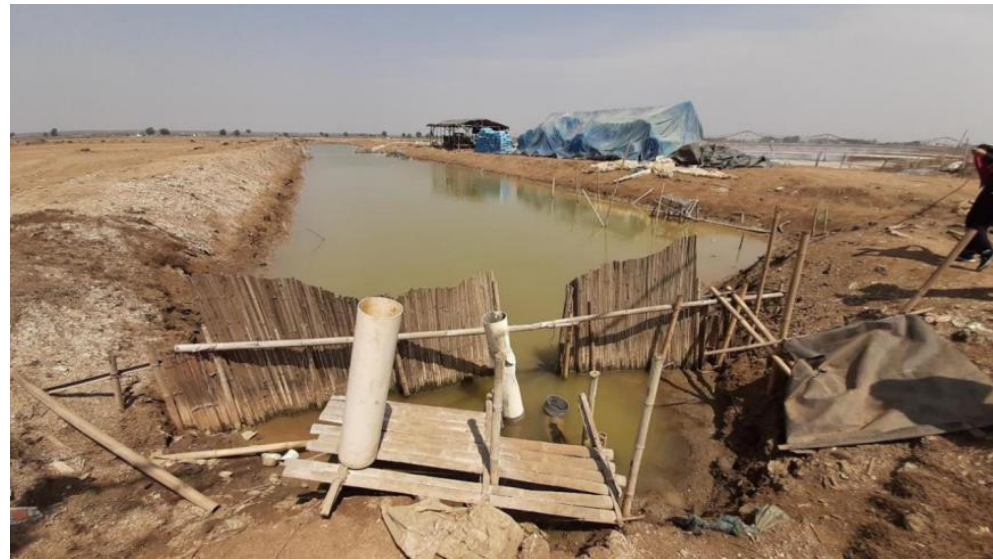

Gambar 2. Saluran Masuk Air Laut Figure 2. Seawater Inlet

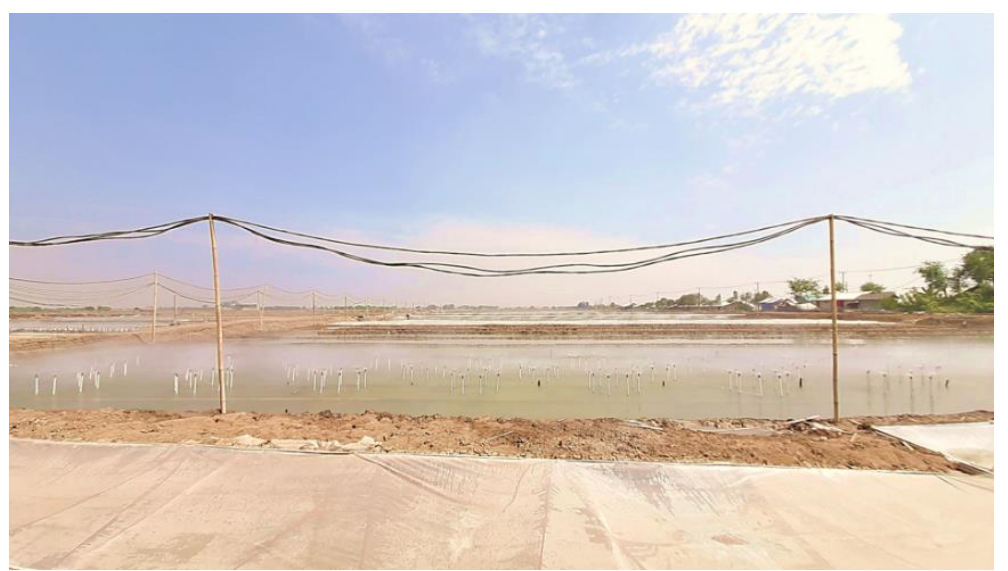

Gambar 3. Pemompaan Air Laut Baku Sebesar $3{ }^{\circ}$ Be ke SP1 (Sprinkle Tingkat Pertama) Figure 3. Pumping of Standard Seawater of $3{ }^{\circ}$ Be to SPI (First Level Sprinkle) 
Selanjutnya proses pengaliran air laut dari petakan sprinkle tingkat pertama (SP1) ke sprinkle tingkat kedua (SP2), proses ini dilakukan berkelanjutan ke sprinkle tingkat ketiga (SP3) dan sprinkle tingkat keempat (SP4) sebagaimana dapat dilihat pada Gambar 4.

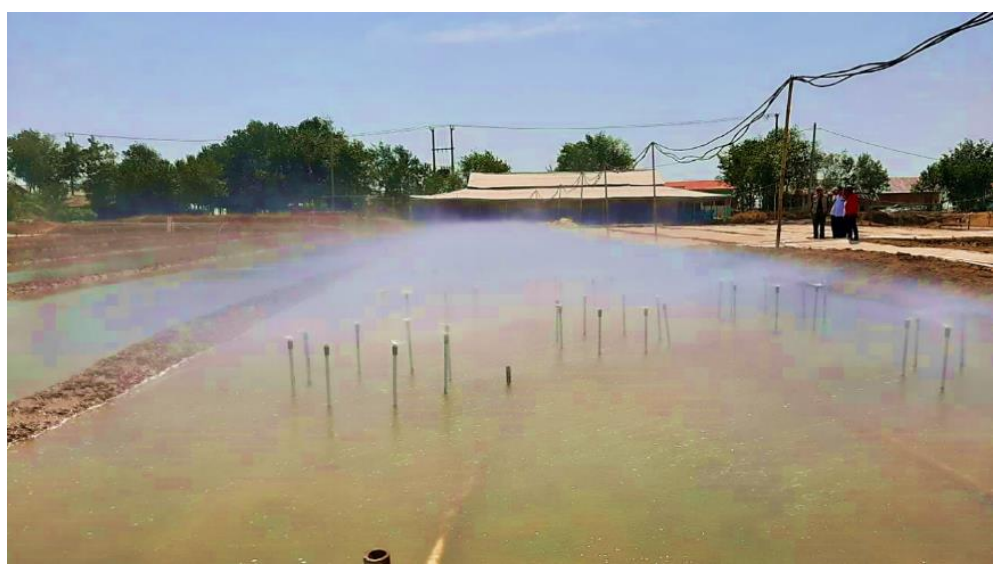

Gambar 4. Pemompaan dari SP1 ke SP2 (Proses ini dilakukan hingga SP4)

Figure 4. Pumping from SP1 to SP2 (This process is carried out up to SP4)

Berdasarkan hasil pengukuran ${ }^{0} \mathrm{Be}$ air laut yang dilakukan pada tambak garam (sprinkle pertama (Sp1) pada jam 10.00 WIB, sprinkle kedua (Sp2) pada jam $12.00 \mathrm{WIB}$, sprinkle ketiga (Sp3) pada jam $14.00 \mathrm{WIB}$, sprinkle keempat (Sp4) pada jam 16.00 WIB), yang dilakukan pengulangan pengukuran ${ }^{0} \mathrm{Be}$ sebanyak 30 kali ulangan dari bulan Agustus sampai dengan bulan Oktober dihasilkan data hasil pengukuran rata - rata sebesar 9,78 ${ }^{\circ}$ Be dengan Metode Sprinkle Bertingkat. Dimulai dari pengisian air laut dengan kadar $3{ }^{\circ}$ Be pada jam 08.00 WIB dan seterusnya selang 2 jam masuk ke SP1 (sprinkle tingkat pertama), SP2 (sprinkle tingkat kedua), SP3 (sprinkle tingkat ketiga) dan SP4 (sprinkle tingkat keempat). Sehingga dengan asumsi untuk menjadi lepas air tua (LAT) pada $25^{\circ} \mathrm{Be}$, maka memerlukan waktu 3 hari, kemudian untuk menjadi kristal garam diperlukan waktu 3 hari, maka keseluruhan waktu yang diperlukan untuk menjadi kristal garam adalah 6 hari.

Tabel 3. Rata - rata Percepatan Penuaan Air Laut Masing - masing Sprinkle

Table 3. Average Acceleration of Aging of Sea Water for Each Sprinkle

\begin{tabular}{lcccccrr}
\hline & \multicolumn{7}{c}{${ }^{0} \mathrm{Be}$} \\
\cline { 2 - 7 } Rata - rata & $\mathrm{Sp} 1$ & $\mathrm{Sp} 2$ & $\mathrm{Sp} 3$ & & $\mathrm{Sp} 4$ \\
& 4.500 & & 5.915 & & 7.333 & & 9.783 \\
\hline
\end{tabular}

Cara paling umum untuk memproduksi garam dari air laut atau air asin adalah kristalisasi melalui penguapan air. Produksi garam surya dapat dilakukan dalam beberapa kolam, sesuai kebutuhan produksi yang akan dihasilkan untuk digunakan berbagai permintaan pasar, antara lain: a) Produksi garam meja: Berat jenis 1,208 menjadi $1,229 \quad\left(27 \quad{ }^{0} \mathrm{Be}\right)$ yang merupakan garam sangat murni.

b) Produksi bahan baku industri: Berat jenis 1,229 menjadi 1,250 atau 1,261 ( $29{ }^{0} \mathrm{Be}$ atau $30{ }^{0} \mathrm{Be}$ ).

c) Memproduksi garam untuk ikan asin: Berat jenis 1,250 - 1,261 menjadi 1,290 ( $\left.32,6{ }^{0} \mathrm{Be}\right)$. 
d) Kebutuhan air laut yang digunakan untuk memproduksi 100.000 ton garam adalah 3.700 .000 ton, yang menghasilkan bittern sebesar 300.000 ton.

\section{BAHASAN}

Hal - hal yang harus diperhatikan dalam pembuatan tambak antara lain tanggul atau pematang tambak harus bebas dari kemungkinan bocor. Untuk menjamin tanggul tidak bocor dapat dilakukan dengan menutup dinding dinding tanggul dengan isolator atau dengan menggunakan dinding beton. Namun, bila menggunakan dinding beton membutuhkan biaya mahal sehingga tidak dianjurkan untuk dipraktekkan secara komersial. Ukuran tambak dapat dibuat sesuai dengan ketersediaan lahan. Hal penting yang perlu diperhatikan dalam mendesain tambak adalah harus ada petakan reservoir, petakan evaporasi dan petakan kristalisasi garam. Teknologi produksi pembuatan garam dengan Metode Maduresse sebagai pembanding teknologi produksi pembuatan garam dengan Metode Sprinkle Bertingkat dapat dijelaskan bahwa teknologi produksi pembuatan garam dengan metode teknologi Maduresse Berisolator (Isolated Maduresse Technology) baik menggunakan HDPE (High Density Polyethylene) maupun LDPE (Low Dencity Polyethylene). Dasar asumsi musim garam selama 5 (lima) bulan dimana 1 (satu) bulan untuk penyiapan lahan dan 4 (empat) bulan untuk proses produksi pembuatan garam (setara dengan 120 hari) maka 1 kali proses produksi (penyiapan air muda, penuaan air sampai panen) selama 12 (dua belas) hari. Sehingga dalam satu musim, tersedia 10 (sepuluh) kali produksi garam. Jika target produksi garam dengan teknologi Maduresse Berisolator sebesar 300 ton per musim maka dalam satu kali produksi garam harus diperoleh 30 ton (Efendy \& Heryanto, 2014).
Jika dibandingkan dengan Metode Maduresse Berisolator yang memerlukan waktu 12 hari, maka terjadi percepatan pembuatan garam selama 6 hari dengan menerapkan Metode Teknologi Sprinkle Bertingkat. Beberapa kelebihan metode teknologi Sprinkle Bertingkat, antara lain meningkatkan produktivitas hasil panen garam dari 30 ton per panen atau 300 ton per musim menjadi 60 ton per panen atau 600 ton dalam satu musim produksi garam, mudah diterapkan sebagai inovasi teknologi produksi garam, serta biaya penambahan alat berupa sprinkle yang tidak mahal.

Metode penguapan air dari air laut atau air asin yang berongkos energi terkecil adalah penguapan dengan sinar matahari (energi surya); umumnya dilakukan di lahan terbuka. Produktivitas tahunan garam suatu lahan di lahan terbuka merupakan fungsi dari selisih antara laju penguapan dan curah hujan. Makin besar selisih makin produktif lahannya. Dalam $1 \mathrm{~mm}$ penguapan pada lahan terbuka seluas 1 hektar sama dengan pelepasan 10 ton air (Soerawidjaja, 2002).

Selanjutnya adalah penggunaan geoisolator yang berbahan plastik HDPE maupun LDPE. Baekhaki et al., (2017) menyebut penggunaan geoisolator sebagai impermeable liner atau material kedap air, selain mempunyai impermeabilitas yang tinggi juga sangat tahan terhadap ultraviolet dan bahan kimia yang berbahaya, sehingga sangat baik untuk menghindari tercemarnya air tanah dari limbah air kotor maupun limbah berbahaya yang ditampung kolam. Selain digunakan untuk memproduksi garam, lahan garam di Indonesia termasuk di Indramayu umumnya digunakan untuk kegiatan budidaya ikan saat musim hujan. Hal ini mengakibatkan sisa-sisa pakan dan ekskresi ikan mengendap di permukaan tanah dan berpotensi menjadi polutan. Geoisolator dianggap mampu mengurangi resiko tercemarnya bahan baku garam dengan limbah atau kotoran tersebut, terutama jika dipadukan dengan filter 
yang baik pada lahan TUF (Teknologi Ulir Filter). Selain lahan TUF, geoisolator juga sering digunakan pada lahan yang menggunakan teknologi Maduresse Berisolator (Isolated Maduresse Technology), yang hasilnya dapat meningkatkan produksi secara signifikan (Efendy et al., 2014).

Menurut hasil penelitian dalam skala laboratorium yang dilakukan oleh Soemargono \& Widodo (2018), pembuatan garam rakyat dilakukan dengan cara pengambilan garam yang ada dalam air laut dengan metode penguapan alami dengan sinar matahari. Proses itu mulai dari penanganan pemasukan air laut hingga pemanenan garam berlangsung kurang lebih selama 1 bulan. Pada saat musim hujan apalagi dengan cuaca yang tidak menentu yang terkadang hujan turun sepanjang tahun menyebabkan produksi garam menurun drastis. Hal itu menjadi penyebab dan penghambat yang signifikan bagi pendapatan petani garam. Untuk mempercepat produksi garam rakyat dilakukan dengan prinsip "kelembaban" yang nilainya tergantung pada suhu. Percobaan ini akan sangat berpengaruh terhadap penguapan air pada air laut. Akhirnya diperoleh air laut dengan kadar garam di dalamnya meningkat. Hasil yang diperoleh pada proses penguapan suhu $40^{\circ}$ C dengan kecepatan aliran udara panas 24 $\mathrm{m} /$ detik dapat menaikkan $5{ }^{\circ} \mathrm{Be}$ menjadi $10{ }^{\circ} \mathrm{Be}$ dalam waktu 42 jam atau menaikkan sampai $25^{\circ} \mathrm{Be}$ dalam waktu 6 hari dan 4 hari pada suhu $44{ }^{\circ} \mathrm{C}$ untuk volume larutan sebanyak 111 liter.

\section{SIMPULAN}

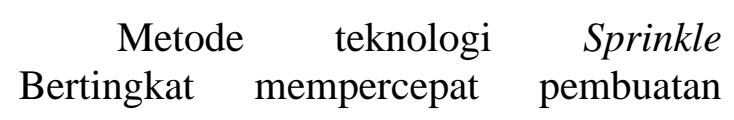

garam menjadi lebih cepat 6 hari, bila dibandingkan dengan metode Maduresse Berisolator yang memerlukan waktu 12 hari dalam 1 kali proses produksi.

\section{DAFTAR PUSTAKA}

Baekhaki, K., Kinseng, R. A., \& Soetarto, E. (2017). Korporatisasi Garam Rakyat : Dinamika Transisi Sosial Ekonomi dan Ekologi Petambak Garam. Sodality: Jurnal Sosiologi Pedesaan, 6(1), 61-70.

Efendy, M., \& Heryanto, A. (2014). Kelayakan Ekonomi Usaha Garam Rakyat dengan Teknologi Maduresse Berisolator. Prosiding Seminar Nasional: Agribisnis dan Pengembangan Ekonomi Perdesaan 1, 83-106.

Efendy M., Heryanto, A., Sidik, R.F. (2014). Korporatisasi Usaha Garam Rakyat. Perspektif Teknik Sosial Ekonomi. Madura: Program Studi Agribisnis, Fakultas Pertanian, Universitas Trunojoyo Madura.

Pranoto, A. K., (2012). Modul Pelatihan Garam Lanjutan. Jakarta: STP Press.

Sartono, C. M., Soedarsono, P., \& Muskanonfola, M. R. (2012). Konversi tonase air dengan berat garam yang terbentuk di areal pertambakan Tanggultlare Jepara. Journal of Management of Aquatic Resources, 2(3), 20-26.

Soemargono \& Widodo, L. U. (2018). Metode Mempercepat Pembuatan Garam Rakyat. Jurnal Teknik Kimia, 12(2), 69-73.

Soerawidjaja, T. H. (2002). Proses Industri Kimia Produk - Produk Anorganik dari Air Laut dan Air Asin Daratan. Bandung: Departemen Teknik Kimia, Fakultas Teknik Industri, Institut Teknologi Bandung. 